\title{
Zn Isotopic Compositions of the Asian Mineral Dust
}

\author{
XINGCHAO ZHANG, JIAN HUANG, YINGZENG GONG, \\ LILI ZHANG AND FANG HUANG
}

CAS Key Laboratory of Crust-Mantle Materials and Environments, School of Earth and Space Sciences, University of Science and Technology of China

Presenting Author: Zhangxc@mail.ustc.edu.cn

Zinc isotopic systematics have been increasingly applied to trace the sources and potential impacts of the atmospherically derived $\mathrm{Zn}$ with both anthropogenic and natural origins. However, better understandings for the $\mathrm{Zn}$ isotopic variations of natural dust are still required. We have performed $\mathrm{Zn}$ isotopic studies in a loess-paleosol profile (S0-L3) from Yimaguan section in central Chinese Loess Plateau (CLP). The loesspaleosol sequences record the dust-climate interaction histories in (semi-) arid region, which can help interrogate $\mathrm{Zn}$ isotopic variations in Asian mineral dust and the response to glacialinterglacial climate changes.

The paleosol with $\mathrm{X}_{\mathrm{fd}}$ (magnetic susceptibility) higher than $10 \times 10^{-8} \mathrm{~m}^{3} \mathrm{~kg}^{-1}$ have slightly lower $\delta^{66} \mathrm{Zn}(0.19 \pm 0.01 \%$, $2 \mathrm{SD} / \sqrt{ } \mathrm{n}$, $\mathrm{n}=11$ ) than loess (unpaired Student's t test, $\mathrm{p}<0.005$ ). The lack of correlations between $\delta^{66} \mathrm{Zn}$ and GT32 (the percentage of particles over $32 \mu \mathrm{m}$ in size) suggests that the glacial-interglacial source fluctuations and particle size-sorting effects (due to wind system changes) are not important for $\delta^{66} \mathrm{Zn}$ variations in loess and paleosol. The leaching residuals by ammonium acetate buffering solusion $(\mathrm{pH}=5)$ display slightly lower $\delta^{66} \mathrm{Zn}$ than bulk samples $\left(\Delta^{66} \mathrm{Zn}_{\text {bulk-residual }}\right.$ from -0.02 to +0.08$)$, indicating a preferential release of isotopically heavy $\mathrm{Zn}$ during chemical weathering. Leachable $\mathrm{Zn}$ fractions $(0.5-3.1 \%)$ show good correlations with leachable $\mathrm{Mn}$ and $\mathrm{Co}(\mathrm{r}>0.8)$, and moderate correlations with leachable $\mathrm{Ca}, \mathrm{Mg}$ and $\mathrm{Sr}(0.8>\mathrm{r}>0.5)$, implying the contributions from carbonates and/or Mn-oxides (desert varnish). Although the leachable $\mathrm{Zn}$ fractions decrease with increasing $\mathrm{X}_{\mathrm{fd}}$, a preferential retention of $\mathrm{Zn}$ is observed for loess with low $\mathrm{X}_{\mathrm{fd}}\left(<6 \times 10^{-8} \mathrm{~m}^{3} \mathrm{~kg}^{-1}\right)$ and homogenous bulk $\delta^{66} \mathrm{Zn}$ $(0.24 \pm 0.01 \%$ o, $2 \mathrm{SD} / \sqrt{ } \mathrm{n}, \mathrm{n}=13)$ which is similar to the value of average upper continental crust (UCC). Our results suggest that the $\delta^{66} \mathrm{Zn}$ variations within loess-paleosol sequences can record pedogenic information in response to climate change. Moreover, the loess from the CLP can represent the average UCC and the dust imported from central Asia in terms of $\mathrm{Zn}$ isotope compositions. 